Article

\title{
The Diverging Understandings of Quality by Coffee Chain Actors-Insights from Colombian Producers and Austrian Roasters
}

\author{
Xiomara F. Quiñones-Ruiz \\ Department of Economics and Social Sciences, University of Natural Resources and Life Sciences, \\ Vienna (BOKU), 1180 Vienna, Austria; xiomara.quinones-ruiz@boku.ac.at; Tel.: +43-1-47654-93339
}

Received: 12 June 2020; Accepted: 28 July 2020; Published: 30 July 2020

\begin{abstract}
This paper addresses the understandings of quality recognized by diverse actors along the coffee chain with focus on specialty coffee producers. In the specialty coffee niche, the assessment of (physical) quality acts as a coordination device among chain actors that enables the identification of divergences on how quality is practiced. This paper aims to uncover how quality attributes (e.g., physical, symbolic) are understood (perceived) by value chain actors and are interwoven with quality conventions (e.g., market, green). Explorative interviews were carried out with Colombian producers located in selected coffee regions. A cupping exercise (tasting of coffee) was organized with producers. Afterwards, another informal cupping was done with roasters in Vienna, Austria. By coupling the concepts of quality attributes and conventions, the paper proposes a theoretical framework that connects quality attributes, conventions and the links to value addition (i.e., from parchment coffee to roasted coffee). Results show that the understandings of quality produce risky battles and ruptures among producers to follow certain conventions. The divergences, risky battles and ruptures in the understandings of quality acknowledged by producers are not only based on "roaster-driven" quality definitions penetrating the producers' community, or the (individual) knowledge gained by producers, but also on the regulatory framework pursued by producers in a country with a strong coffee federation aiming to legitimize and safeguard the product's reputation. To what extent is sound experimentation allowed, and direct exchange and interaction between producers, buyers and roasters desirable? Specialty coffee represents a differentiation alternative for small producers located in remote rural areas. Therefore, a transparent and inclusive dialogue between chain actors is required to reduce the divergences in the understandings of quality to balance the value appropriation along the chain.
\end{abstract}

Keywords: coffee; producers; roasters; quality attributes and conventions; value addition; Colombia; Austria

\section{Introduction}

This paper addresses the understandings of quality acknowledged by diverse actors along the coffee value chain with focus on specialty coffee producers. In the specialty coffee niche, the understandings of material quality (e.g., recognized through physical evaluation, cupping or coffee tasting) and its lexicon are important coordination devices among chain actors [1-4]. Individual or associated producers, roasters, retailers and baristas have the power, knowledge and financial conditions in their hands to create and achieve a certain quality depending on their varied positions and the conventions followed [3,5-8]. For instance, Colombian producers mainly sell parchment coffee (physical quality), while roasters and coffee shop owners pursue symbolic and in-person service quality attributes at the moment of brewing the coffee for end consumers. Therefore, what coffee producers 
sell —mainly in the producing countries—and what end consumers in the North purchase, are totally differently valued coffees [9].

The specialty coffee niche offers an opportunity for producers to differentiate and accrue higher income in the liberalized coffee sector. Indeed, to cope with price instability after the dismantling of the quota system of the International Coffee Agreement in 1989, producers began to look for alternatives and started to access value-added agro-food markets (e.g., Fairtrade as one of the leading voluntary standards). Several studies that analyze the outcomes or impact of these standards are not conclusive or do not provide a clear-cut picture [10-21]. The outcomes of standards are also contested because there are no common measurement methodologies; while some studies find positive socio-economic and environmental effects for producers [22,23], others show no positive effects or mixed results [13,24]. Furthermore, although coffee is one of the leading products complying with voluntary and private standards (e.g., Fairtrade, Organic, Rainforest Alliance, and more recently Geographical Indications), the export value accrued by producing countries has not substantially increased. In fact, while the global coffee production sold was about $75 \%$ in 2016, the export value for production countries only amounted to $10 \%$ of the profits in the coffee retail market [6]. Current news shows the desperate situation of producers, who are even thinking about leaving the trading price of Arabica coffee based on the Intercontinental Exchange (ICE) known as the $C$ price $[25,26]$. The ICE is a major commodity exchange bureau based in New York City, USA. "All coffee is treated as one raw material, regardless of origin or other factors. Even specialty coffee prices are usually linked to the $C$ price, plus a premium" [27] (n.pag.) As of Gilbert [28] (p. 267), the "cake division" fallacy is still observed since "the value at one stage is seen as being at the expense of value at another".

In the coffee sector, voluntary standards have developed considerably but have also become mainstream or a must. Thus, due to the long-term problems faced by producers at origin, apart from engaging in the most common private voluntary standards for coffee, some producers have also embarked on the production of specialty coffee. Certainly, the disappointment with well-known voluntary standards has animated some producers but also roasters to look for further differentiation alternatives, namely the specialty coffee niche based on direct "relationship coffees", to improve producers' livelihoods as well as roasters' corporate image [4]. Wollni and Zeller [29] illustrate how participation in specialty coffee markets and in cooperatives led to a price increase for producers in Costa Rica. Nonetheless, although market regulations have aimed at guaranteeing fair distribution of coffee incomes among all actors, they have also limited the expansion of "new market segments and the remuneration of higher-quality coffee" [30] (based on [29], p. 247).

Vicol et al. [4] define relationship coffees as traded coffees based on a direct producer-roaster relationship guided by personal visits, transparency, trust, high quality, as well as social and environmental sustainability. However, producers in developing and transition countries still face challenges in achieving high quality and consistency [31]. MacGregor et al. [32] found that direct trading has also been initiated as a tool to enhance coffee quality and producers' incomes and to establish regular communication. Nevertheless, initial direct trade pioneers are facing challenges along with other coffee firms' efforts to avoid the co-optation of the term direct trade, since it is now being mainly used as a marketing tool overlooking its initial founding principles [32,33].

The participation of (well-informed or knowledgeable) producers in the specialty coffee niche (cafés especiales) needs to be carefully gauged. Specialty coffee might comprise approximately $27 \%$ of the global supply for washed Arabicas [3] in which the physical quality attributes of the beans play a decisive role. This paper aims to unpack the understandings of quality recognized by value chain actors such as producers as well as the conventions followed. Coffee producers based in rural and remote areas are mainly seen as providers of the physical attributes [9]. Smallholder coffee producers mostly associate quality with farm practices rather than with the enjoyment of a good cup of coffee [9]. Hence, quality is seen as the outcome of what producers do at farm level and "the indicator is the [physical/material] appearance of coffee beans at the first change of hands between farmer and primary-level trader or processor" [9] (p. 131). Producers need to follow certain quality 
conventions expected by downstream chain actors such as international buyers and roasters to be able to participate in the specialty coffee niche. Thus, quality conventions are regarded as outcomes of social processes and collective choice. In other words, quality conventions are understood as mechanisms to organize the co-operation of several economic actors-a situation that cannot be mastered exclusively by an individual decision maker [34]. Quality emerges from a negotiation process among actors guided by principles that justify their actions based on the market or on certain standards or principles (e.g., environment-related practices) [35]. Hernández-Aguilera et al. [36] studied the environmental, socio-economic and technological outcomes for smallholders involved in a Relationship Coffee Model between coffee buyers and smallholders based on an established product quality. The analyzed Colombian producers using the model engaged in more sustainable resource management practices such as water-saving techniques, soil protection, biological control methods or retention of high tree diversity. However, the adoption of the environmental practices was not a direct goal of the Relationship Coffee Model but rather the consequence of employing shade-grown and organic production practices (green conventions) to improve product quality.

Thus, this paper aims: (1) to propose a theoretical framework that connects quality attributes, conventions and the links to value addition (i.e., from parchment coffee to roasted coffee), and (2) to encourage the debate on the emerging interdependencies observed in the specialty coffee sector. First, I carried out exploratory interviews and informal cupping exercises (sensory evaluation of coffee) with selected producers in Huila and Santander, Colombia. Then, an informal cupping exercise was pursued with Viennese roasters to understand how they perceive the sensory quality of coffee. Convention approaches show that quality, instead of price or quantity, is essential to organize production and markets [37].

In this order of ideas, the next section builds upon a theoretical quality framework that guides the paper. Section three describes the methods used. Section four shows the results based on explorative interviews and cupping exercises with producers and roasters to define quality. Finally, sections five and six present the discussion and the conclusions, respectively.

\section{Quality Conventions}

\subsection{Convention Theory from Economic Sociology}

Convention theory from economic sociology [38] is a common approach used for studying the 'quality turn' in agro-food studies [39]. French scholars such as Luc Boltanski, Alain Desrosières and the economists François Eymard-Duvernay, Olivier Favereau, Robert Salais and Laurent Thévenot have aimed to develop explanations based on the areas in which actors need to negotiate to establish shared understandings of subjects [40]. According to Diaz-Bone and Salais [41] (p. 7), "conventions are interpretative schemes for action and coordination that persons and actors use in situations under conditions of uncertainty". In other words, they "are the way institutions are interpreted and handled in situations" [41] (p. 9).

Conventions can be regarded as "the implicit collective knowledge present in situations, and the skills of how to apply them are part of the competencies that actors have" for the production of certain qualities (e.g., goods and processes) [35] (p. 71). Ponte [39] (p. 13) looks at conventions "as systems of reciprocal expectations about the behavior of others". Convention theory regards quality as a result of communication on and negotiations (coordination) of product quality criteria [34,42]. These criteria are synthesized in specific practices and procedures used as objective references to produce specific material, symbolic and in-person service attributes. Quality conventions and the guiding justifications (such as market, industrial, civic, or green) are important coordination mechanisms along global chains. The diverse quality conventions followed by chain actors create realities and can serve as differentiation tools [43] and coordination devices [1]. According to Boltanski and Thévenot [44], conventions occur regularly in hybrid rather than pure forms, namely through compromises among them (Table 1). For instance, the required innovative capacity (inspired convention, Table 1) of specialty producers (e.g., 
when using specific coffee varieties and novel post-harvest processing trials) and roasters (i.e., when deciding the use of determined origins in blends) is necessary to navigate in the specialty coffee niche. As shown by Hernández-Aguilera et al. [36], to be able to innovate, special focus on the resources (e.g., soil) is needed to produce certain quality. In other words, attaining specific product quality might be reached with green justifications embedded in organic conventions.

Table 1. The eight conventions.

\begin{tabular}{|c|c|c|c|c|c|}
\hline Convention & $\begin{array}{l}\text { Worth/ } \\
\text { Quality }\end{array}$ & Evaluation Criteria & $\begin{array}{l}\text { Information } \\
\text { Format }\end{array}$ & $\begin{array}{c}\text { Personal } \\
\text { Qualification }\end{array}$ & $\begin{array}{c}\text { Interpersonal } \\
\text { Relation }\end{array}$ \\
\hline Domestic & $\begin{array}{l}\text { Tradition, } \\
\text { handcraft }\end{array}$ & $\begin{array}{c}\text { Esteem, } \\
\text { reputation }\end{array}$ & $\begin{array}{c}\text { Oral, } \\
\text { exemplary }\end{array}$ & $\begin{array}{c}\text { Authority } \\
\text { and flexibility }\end{array}$ & Trust \\
\hline Market & $\begin{array}{c}\text { Demand } \\
\text { orientation, } \\
\text { free exchange }\end{array}$ & Price & $\begin{array}{l}\text { Money } \\
\text { units }\end{array}$ & $\begin{array}{c}\text { Desire, } \\
\text { purchasing } \\
\text { power }\end{array}$ & Exchange \\
\hline Industrial & $\begin{array}{c}\text { Planning and } \\
\text { standardization }\end{array}$ & Efficiency, productivity & $\begin{array}{c}\text { Measurable } \\
\text { criteria, statistics }\end{array}$ & $\begin{array}{c}\text { Professional } \\
\text { expertise }\end{array}$ & $\begin{array}{l}\text { Functional } \\
\text { link }\end{array}$ \\
\hline Inspired & $\begin{array}{l}\text { Grace, nonconformity, } \\
\text { creativity }\end{array}$ & $\begin{array}{l}\text { Originality, innovative } \\
\text { capacity }\end{array}$ & $\begin{array}{c}\text { Newness, } \\
\text { emotionality }\end{array}$ & Creativity, ingenuity & Passion \\
\hline Opinion & Renown & Amount of recognition & Semiotics & Celebrity & Recognition \\
\hline Civic & $\begin{array}{l}\text { Collective } \\
\text { interest }\end{array}$ & Relevance for collective & $\begin{array}{l}\text { Formal, } \\
\text { official }\end{array}$ & Equality & Solidarity \\
\hline Green & $\begin{array}{c}\text { Ecology } \\
\text { (its integrity) }\end{array}$ & $\begin{array}{l}\text { Environmental } \\
\text { compatibility }\end{array}$ & Narrative & $\begin{array}{l}\text { Ecological } \\
\text { knowledge }\end{array}$ & Responsibility \\
\hline Network & $\begin{array}{c}\text { Activity, } \\
\text { self-management }\end{array}$ & $\begin{array}{l}\text { Successful } \\
\text { projects }\end{array}$ & Meetings & $\begin{array}{l}\text { Capacity for } \\
\text { teamwork }\end{array}$ & $\begin{array}{c}\text { Project } \\
\text { orientation }\end{array}$ \\
\hline
\end{tabular}

Source: [35] (p. 73).

Neglecting the given justifications to follow certain quality conventions (Table 1), the type of power exerted and the frictions among these "would result in missing one of the most important aspects of the transformation of agriculture and contemporary rural life itself for it is through standards that the moral economy is produced and reproduced" [37] (p. 274).

\subsection{Defining Quality}

Quality is a trait difficult to define [45] (p. 30). According to the International Organization for Standardization (ISO) quality is defined as "the ability of a set of inherent characteristics of a product, system or process to fulfil requirement of customers and other interested parties" [46] (cited by [45], p. 230).

Daviron and Ponte [9] suggest three attributes to define quality in the coffee sector: (1) material attributes, physical transformations and measurement; (2) symbolic attributes; and (3) in-person service attributes.

The first type refers to 'intrinsic' and/or 'objective' attributes. They are regarded as being independent from the identification of value chain actors such as primary sellers and international buyers. In physical, chemical or biochemical processes, specific physical parameters are created and/or selected. Thus, the value of material quality attributes mainly relates to the existence of well-established and accurate measurement operations and devices [9]. Symbolic attributes cannot be measured by human senses or complex technological devices. They are based on reputation often embedded in trademarks, geographical indications, and other voluntary standards. While "trademarks enable the 'consumption of an enterprise', geographical indications promote the 'consumption of a place'. Sustainability labels [e.g., Fairtrade] make it possible to 'consume ethics'. The reputation is obtained through repeated consumption experiences and advertising" [9] (p. 37). For instance, Fairtrade initiatives attempt to incorporate multiple symbolic quality attributes into the certified products concerned. Goods can be classified into different categories on the basis of how information is conveyed to and/or accessed by consumers (search, experience and credence) [47]. Search attributes are characteristics examined by consumers before purchasing the product (e.g., price, size and color); experience attributes are evaluated after purchasing (e.g., taste) [48], while credence attributes are aspects that consumers cannot evaluate before or after purchase [49]. Those 
attributes that consumers cannot assess (before purchasing) are often communicated by labels. In-person service attributes can be regarded as "the immaterial dimension of modern capitalism" [9] (p. 44). That is, the in-person service attribute is the relation between the employees at the cafés and the consumers, including affective labor [9] (p. 46).

The three quality attributes are illustrated as follows. Material attributes relate to taste, aroma and appearance of an espresso or cappuccino the consumer buys and drinks (or a roaster looks for). Symbolic attributes are linked to subjective characteristics. For instance, Starbucks is a worldwide brand recognized for offering diverse coffee origins (consumption of places) at coffee shops characterized by voguish interior design and ambiance. The in-person service attribute represents the relation between employees (e.g., baristas) and end consumers at specialized coffee shops at the moment of consumption [9].

\subsection{Measuring Quality}

In producing countries, green coffees are normally evaluated based on the material attributes through physical parameters such as color, size, number of defects by using more or less sophisticated mechanical and optical separation and sorting processes. However, aroma and taste of specialty coffees in countries with well-defined quality regulations (e.g., Colombia) are additionally assessed through sensory inspection prior to exports. Therefore, the definition, understanding and appreciation of quality depends on the actor's position in the value chain.

In January 2017, the Specialty Coffee Association of America (SCAA) and the Specialty Coffee Association of Europe (SCAE) merged into the Specialty Coffee Association (SCA) [50]. The SCA has developed the lexicon, protocols and best practice tools concerning green coffee grading, cupping protocols, brewing and the separation of coffee products [51,52]. These are the most common tools to evaluate the material or physical quality of specialty coffees [52]. SCA protocols are suggested "to guarantee the ability to evaluate coffee with the highest quality (material attributes) through coffee cupping tests" [53] (p. 402). Specifically, coffee cupping tests consist of three samples to be able to: "(1) determine real sensory differences between coffee samples, (2) describe the taste of the samples, (3) determine preference for different types of coffee" [53] (p. 402). Based on the SCA [52], the scoring format for the cupping test allows to register the following attributes of coffee such as fragrance - smell of the ground coffee when still dry, while aroma is the smell of coffee when infused with hot water; aftertaste- the length of positive flavor qualities (taste and aroma) emanating from the back of the palate and remaining after the coffee is expectorated or swallowed; acidity_-"brightness" when favorable or "sour" when unfavorable; body-tactile feeling of liquid in the mouth, especially perceived between the tongue and roof of the mouth; among many other attributes as well as defects, which are the negative or poor flavors that detract from the quality of the coffee.

To calculate the SCA final score, individual scores of every primary attribute in the box marked "total score" are totaled and defects are subtracted [51]. Coffees reaching 80 points (Table 2) and more are considered as specialty coffees [52]. Very well-trained tasters (e.g., Q-graders) use SCA forms to record the results of a cupping test and to determine the coffee quality [52]. Since results and information are documented in paper form for all sensory panels, Gutiérrez-Guzmán et al. [53] propose a web platform designed by Cesurcafé (Coffee Research Center (CRC) located at the Universidad Surcolombiana) to enable the storing and processing of the results of cupping tests for specialty coffees to promote accessibility and transparency.

Table 2. SCA final scores and classifications for specialty coffees.

\begin{tabular}{ccc}
\hline Total Score & Quality & Classification \\
\hline $90-100$ & Outstanding & Specialty \\
$85-99.99$ & Excellent & Specialty \\
$80-84.99$ & Very good & Specialty \\
$<80$ & Below specialty quality & Not specialty \\
\hline & Source: $[52]$.
\end{tabular}




\subsection{Linking the Quality Attributes and the Quality Conventions}

According to Diaz-Bone [35] (p. 80), "the economics of convention relates conventions to products as foundations for their quality". Therefore, the users of this approach speak of quality conventions. This paper aims to unpack the interpretative schemes for actions followed by selected chain actors, since there is a need to discover at the grass roots what producers and roasters understand by quality and how this is reflected in their (justified) activities. By coupling both quality attributes and conventions (Figure 1), one cannot only grasp the need for coordination, the information, knowledge and power exerted by value chain actors (see [5]) along the global chains, but also how production and consumption processes are guided or institutionalized. By intertwining the concepts of quality attributes and conventions, this paper endeavors to propose a theoretical framework that connects quality attributes, conventions and value addition along the coffee chain accrued by producers (Figure 2). The main nodes along the global coffee value chain include actors in producing countries such as smallholders, commercial producers or larger estates, and upstream processors and exporters. Normally, transactions among them are mediated by local traders. The export of green coffee is usually run by international buyers, before downstream processors such as roasters and retailers sell roasted coffee via various distribution channels [54] (Figure 2). This paper results from the initial implementation of a research project that aims to study producers, their respective international buyers and roasters at a greater scale and the respective debates (divergences and/or convergences) about the understandings of quality and value addition (which are, however, not covered in this paper yet).

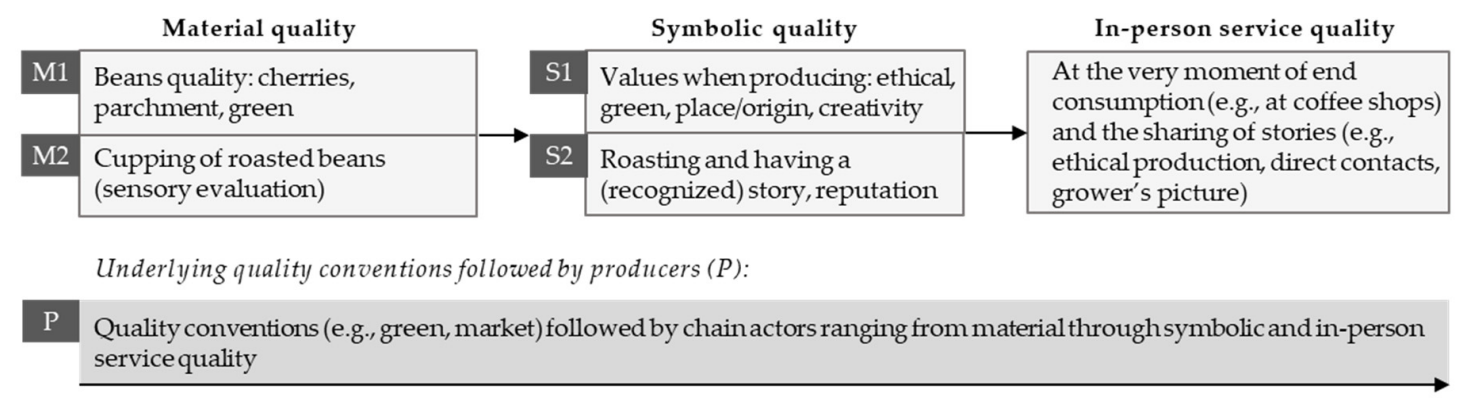

Figure 1. Linking quality attributes and conventions as mechanisms for coordination and value addition (e.g., from parchment to roasted coffee) along the coffee value chain. Source: Own elaboration.

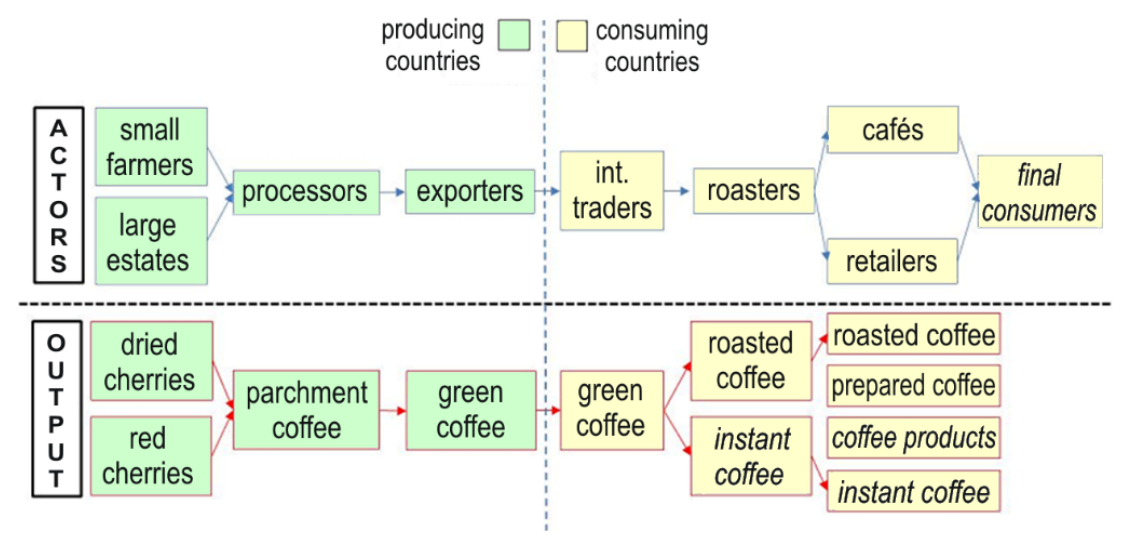

Figure 2. Global coffee commodity value chain. Source: Adapted from [54] (p. 9).

\section{Methods}

The empirical work of this paper consists of three parts:

(1) Getting to know the producers at origin. First, on 6-18 November 2018 and 18-26 March 2019, I pursued exploratory and open interviews with producers in Huila and Santander (Colombia) 
to become acquainted with them and to grasp their understanding of quality and conventions followed to achieve or construct a certain coffee quality. Huila and Santander were selected because: (i) these states are recognized as quality coffee producing states within Colombia; and (ii) they have been granted with local geographical indications in Colombia (e.g., Café de Huila in 2013, Café Santander in 2014). During the process of accessing the producers, I got support from senior coffee researchers based at two universities (Universidad Surcolombiana in Neiva, Huila; Universidad Libre in Socorro, Santander). Producers were deliberately selected via purposive sampling in these two states. The early exchange with researchers and producers allowed me to fine-tune the research design (e.g., interview guidelines) for the main fieldwork planned for a later stage.

(2) Cupping with producers at origin. As a next step, I coupled the interviews with informal cupping exercises with selected producers in Huila. These cupping exercises were carried out to perceive how producers would define coffee quality after tasting their own coffee with peers.

(3) Cupping with roasters at destination. I took various coffee samples from producers I had previously visited and some others advised by a local coffee research center (CRC) in Huila. Then, upon my arrival in Vienna, where I am based, I contacted a specialty roaster, with whom I had previously done some research, to organize an informal cupping exercise with Viennese roasters using the coffee samples from some producers. This roaster acted as an expert and the entry point to Viennese and Austrian specialty roasters and buyers who are not that easy to access. It is worth noting that while it is much easier to contact producers in the field, the exchange with roasters and international buyers needs to be carefully gauged. The very informal cupping event took place at a small Viennese coffee shop on 2 May 2019. Only three roasters attended the event (including the roaster I previously knew). It was the first time that such event had been co-organized. The main goals were to identify some Viennese roasters and to find out how they would assess the sensory quality of the coffee samples (but also to see if they would buy the coffee). While all samples from Huila were cupped at the labs following the SCA protocol at the CRC, the cupping with roasters in Vienna was rather informal (e.g., only two cups per sample following a self-elaborated and simplified cupping form based on the SCA protocol). Interviews with roasters were not planned at this stage. It is worth noting that consumers are not included in this study due to time and financial constraints.

The qualitative approach carried out in the form of explorative and open interviews with researchers and producers intended to immerse them in the research topic and to establish relationships with (potential) interviewees in view of the proposed theoretical framework [55]. The interviews were not voice recorded, but field notes were taken during the meetings whose content was then analyzed. The five coffee producers visited in San Adolfo, Acevedo, Pitalito (Huila) and Socorro (Santander) are coded as $P_{1}, P_{2}, P_{3}, P_{4}$ and $P_{5}$. The roasters are coded as $R_{1}, R_{2}$ and $R_{3}$.

\section{Results}

This section presents the results of: (1) the exploratory interviews carried out in Huila and Santander (understandings of quality by producers and an informal cupping exercise with them), and (2) the sensory assessment of coffee quality by roasters during an informal cupping exercise.

All interviewed producers were able to specify the material or physical attributes of their coffees (Table 3). In Huila, producers stated what they need to do to produce a good coffee. $\mathrm{P}_{1}$ showed diverse varieties and specified the relevance of soil nutrition, the role of organic compost as well as of the altitude. $\mathrm{P}_{1}$ also stated that he has other farms at a higher altitude. All these aspects were mentioned as relevant to obtaining (material) quality. $\mathrm{P}_{2}$ said he has started to dry parchment coffee with eucalyptus and showed the diverse varieties he has planted. He also stated that he only processes quality coffee lots using the semi-washed method. None of the producers that commercialize roasted/packaged coffee roast their coffees by themselves. Producers pay for threshing, roasting and packaging services in the main towns (i.e., Pitalito, Neiva, Socorro). Only two producers $\left(\mathrm{P}_{1}, \mathrm{P}_{4}\right)$ have a registered trademark for 
roasted coffee. $\mathrm{P}_{1}$ has recently set up a small quality lab at his farm. Indeed, $\mathrm{P}_{1}$, as a recognized coffee producer, organized the first "Feria de Café Especial 'Tierra del Bourbon Rosado'" (a specialty coffee fair) in October 2018 to promote producers and the coffee origin from San Adolfo (Bourbon Rosado), despite the resistance of local coffee authorities. $\mathrm{P}_{1}$ aimed to promote a place and therefore the consumption of a place. During my visit, $\mathrm{P}_{1}$ also served as contact to other producers.

It is worth noting that $P_{1}$ is a veterinary physician who decided to engage in coffee as his father wanted to sell the farm a couple of years previously due to the recurrent low prices. His father was fed up with coffee farming and used to sell coffee to the local cooperative or intermediaries. Before $\mathrm{P}_{1}$ took over the farm, he spent a couple of months in Guatemala and Panamá, countries well known for producing high quality coffees, to understand more about the specialty coffee niche. In that way, $\mathrm{P}_{1}$ got to know new varieties, varietals and processing techniques not used by his father. In some places, $\mathrm{P}_{1}$ bought seeds or got them for free. $\mathrm{P}_{1}$ started then to gain knowledge on coffee farming, established contacts with local and international roasters, created a family company and has become a kind of focal point in his town (San Adolfo). $\mathrm{P}_{1}$ is able to attend international coffee fairs where he becomes knowledgeable of the specialty coffee market abroad. Likewise, he has welcomed international and national buyers and roasters at his farm since his name is known as a specialty coffee producer in the region. Indeed, the CRC advised me to contact $\mathrm{P}_{1}$.

By observing producers in San Adolfo, I could grasp how they interact and collaborate by exchanging information, experiences or by asking questions when experimenting with new varieties or post-harvest trials. In fact, when I visited $\mathrm{P}_{2}$, he was constantly asking $\mathrm{P}_{1}$ about tree pruning. Interestingly, most varieties used by producers in Santander were the ones recommended by Cenicafé (e.g., Castillo as leaf-rust-resistant variety), whereas producers in Huila used other varieties such as Bourbon Rosado, Bourbon Amarillo, Geisha, Pacamara, in addition to Castillo.

Figure 2 illustrates the quality attributes and conventions recognized by producers as well the scope of added value (e.g., production of parchment coffee, green coffee and/or roasted coffee, cup of coffee served at a coffee shop). $\mathrm{P}_{1}$ and $\mathrm{P}_{4}$, as specialty coffee producers, aim to receive a recognition for their coffee farming and pursue diverse coordination mechanisms. Producers in Huila are open to innovate and experiment (M1) (Figure 2) as far as knowledge is available (educated producers or via direct contact with international buyers/roasters). This leads to the engagement in inspirational or notoriety conventions. $\mathrm{P}_{1}$ mentioned the exchange with a specific European buyer/roaster based in Colombia to improve the cup quality (M1 + M2). Despite being part of the specialty coffee niche, $\mathrm{P}_{1}$ also devotes special attention to soil nutrition by partially using organic compost and organic foliar fertilization. Thus, $\mathrm{P}_{1}$ follows diverse coordination mechanisms to achieve his material and symbolic quality. After the knowledge obtained through his trips and (foreign) exchanges with other chain actors, $\mathrm{P}_{1}$ decided to do something different (inspired convention) and in that way avoid the selling of the family farm. Additionally, $\mathrm{P}_{1}$ attempts to produce specialty coffee following certain green conventions (using organic compost without being organic-certified). 
Table 3. Identified quality understandings and conventions.

\begin{tabular}{|c|c|c|c|c|c|}
\hline \multirow{2}{*}{$\begin{array}{c}\text { Description } \\
\text { of Chain Actor }\end{array}$} & \multicolumn{3}{|c|}{$\begin{array}{l}\text { Identified Coffee Quality Attributes } \\
\text { According to Daviron and Ponte [8] }\end{array}$} & \multirow{2}{*}{$\begin{array}{l}\text { Own Definition of Coffee Quality } \\
\text { at Explorative Cupping with } \\
\text { Producers }\end{array}$} & \multirow{2}{*}{$\begin{array}{l}\text { Producers' Positions along the } \\
\text { Coffee Value Chain }\end{array}$} \\
\hline & $\begin{array}{c}\text { Material/ } \\
\text { Physical Attributes }\end{array}$ & $\begin{array}{l}\text { Symbolic } \\
\text { Attributes }\end{array}$ & $\begin{array}{c}\text { In-Person } \\
\text { Service Attributes }\end{array}$ & & \\
\hline $\begin{array}{c}\text { Son of a coffee producer, } 36, \\
\text { veterinarian, owns more than } 20 \\
\text { hectares located in different lots, } \\
\text { dedicated to coffee production } \\
\text { since } 2014 \text {; although he does not } \\
\text { belong to any producer group, he } \\
\text { exchanges and shares with local } \\
\text { producers }\left(\mathrm{P}_{1}\right) \text {. }\end{array}$ & $\begin{array}{l}\text { Outstanding knowledge on quality, not } \\
\text { only being aware of physical defects in } \\
\text { green coffee, but is also able of tracing } \\
\text { back and acknowledging the } \\
\text { agro-environmental offer (use of } \\
\text { diverse varieties/varietals such as } \\
\text { Bourbon Amarillo, Bourbon Rosado, } \\
\text { Geisha, Pacamara but also Castillo*; } \\
\text { soil nutrition, organic compost; } \\
\text { microclimate; altitude) and diverse } \\
\text { processing techniques (e.g., wet, honey, } \\
\text { natural) influencing quality. } \\
\text { Additionally, he has participated in } \\
\text { specialty coffee competitions and is an } \\
\text { experienced cupper (not certified). }\end{array}$ & $\begin{array}{l}\text { He values and pays attention to the } \\
\text { environmental conditions; e.g., for him } \\
\text { soil nutrition and organic com-post } \\
\text { influence the quality of the cherries. } \\
\text { He also has a registered trademark to } \\
\text { sell roasted coffee (ground, beans) after } \\
\text { paying for threshing and roasting } \\
\text { services, however, he stated that the } \\
\text { roasting he gets might not be suitable } \\
\text { for the European market, "we are } \\
\text { learning about roasting", he said. He } \\
\text { organized the first specialty fair "Feria } \\
\text { de Café Especial 'Tierra del Bourbon } \\
\text { Rosado" in San Adolfo to promote the } \\
\text { local variety. }\end{array}$ & $\mathrm{n} / \mathrm{a}$ & $\begin{array}{l}\text { He easily describes the coffee } \\
\text { following the SCA lexicon ("tonos } \\
\text { de chocolate, muy aromático, acidez } \\
\text { media, cuerpo cremoso, residual } \\
\text { prolongado"); he supported other } \\
\text { porticipants to start cupping as } \\
\text { some producers were shy at the } \\
\text { beginning. }\end{array}$ & $\begin{array}{l}\text { This producer considers himself } \\
\text { not only as a producer but also as } \\
\text { an entrepreneur (adapting to } \\
\text { market trends); he has managed to } \\
\text { export directly to specialty roasters } \\
\text { (small quantities), albeit mainly } \\
\text { green coffee to importers in North } \\
\text { America and Asia; he has also } \\
\text { managed to export small lots of } \\
\text { roasted coffee to Asia; one small } \\
\text { portion is also roasted with his } \\
\text { trademark for the local market } \\
\text { (including specialty coffees). }\end{array}$ \\
\hline $\begin{array}{c}\text { Son of a grower, } 33 \text {, inherited the } \\
\text { land, } 2 \text { hectares, exchanges with a } \\
\text { local association }\left(\mathrm{P}_{2}\right) \text {. }\end{array}$ & $\begin{array}{l}\text { Aware of the material quality (e.g., } \\
\text { defects), the varieties (e.g., Bourbon } \\
\text { Rosado but also Castillo); he attempts } \\
\text { new forms of drying coffee with } \\
\text { eucalyptus leaves to improve material } \\
\text { quality; } \mathrm{P}_{1} \text { suggested him because of } \\
\text { the innovation of drying with leaves. }\end{array}$ & $\mathrm{n} / \mathrm{a}$ & $\mathrm{n} / \mathrm{a}$ & $\begin{array}{l}\text { Identified his coffee after a second } \\
\text { attempt, described it with "sabores } \\
\text { aromáticos, buen dulzor"; } \\
\text { however, he said "no tengo } \\
\text { experiencia en esto" [I have no } \\
\text { experience in this]; } \mathrm{P}_{1} \text { stated later } \\
\text { on that he had enrolled in a } \\
\text { cupping training after this exercise. }\end{array}$ & $\begin{array}{l}\text { He mainly sells parchment coffee to } \\
\text { local cooperatives, associations and } \\
\text { traders (comercio). }\end{array}$ \\
\hline $\begin{array}{l}\text { Father, 62, daughter, } 31 \text { (teacher), } 8 \\
\text { hectares }\left(\mathrm{P}_{3}\right) \text {. }\end{array}$ & $\begin{array}{l}\text { Aware of the basic material quality } \\
\text { knowledge, relatively new to coffee } \\
\text { production (former livestock producer); } \\
\text { the main variety cropped is Castillo. }\end{array}$ & $\mathrm{n} / \mathrm{a}$ & $\mathrm{n} / \mathrm{a}$ & $\begin{array}{l}\text { After some attempts, both (father } \\
\text { and daughter) identified their } \\
\text { coffee with support of a CRC } \\
\text { member staff; nevertheless, they } \\
\text { could not describe it with their own } \\
\text { words. }\end{array}$ & $\begin{array}{l}\text { Although they do not belong to any } \\
\text { producer group, they sell } \\
\text { parchment coffee to the cooperative } \\
\text { by chance his daughter got to know } \\
\text { a specialty roaster and sold the } \\
\text { coffee to him (after the second } \\
\text { sample was accepted since some } \\
\text { issues concerning drying were } \\
\text { affecting the quality) through the } \\
\text { services of a local exporter. }\end{array}$ \\
\hline
\end{tabular}


Table 3. Cont

\begin{tabular}{|c|c|c|c|c|c|}
\hline \multirow{2}{*}{$\begin{array}{l}\text { Description } \\
\text { of Chain Actor }\end{array}$} & \multicolumn{3}{|c|}{$\begin{array}{l}\text { Identified Coffee Quality Attributes } \\
\text { According to Daviron and Ponte [8] }\end{array}$} & \multirow{2}{*}{$\begin{array}{l}\text { Own Definition of Coffee Quality } \\
\text { at Explorative Cupping with } \\
\text { Producers }\end{array}$} & \multirow{2}{*}{$\begin{array}{l}\text { Producers' Positions along the } \\
\text { Coffee Value Chain }\end{array}$} \\
\hline & $\begin{array}{c}\text { Material/ } \\
\text { Physical Attributes }\end{array}$ & $\begin{array}{l}\text { Symbolic } \\
\text { Attributes }\end{array}$ & $\begin{array}{c}\text { In-Person } \\
\text { Service Attributes }\end{array}$ & & \\
\hline $\begin{array}{l}\text { Producer, } 50,10 \text { hectares, part of an } \\
\text { association for } 15 \text { years; he also } \\
\text { repairs pulping machines }\left(\mathrm{P}_{4}\right) \text {. }\end{array}$ & $\begin{array}{l}\text { Became more aware of the material } \\
\text { quality (farming and processing) after } \\
\text { he was ranked fifth in the Taza de la } \\
\text { Excelencia (Cup of Excellence) in } 2012 \text {. }\end{array}$ & $\begin{array}{l}\text { After the Cup of Excellence, he started } \\
\text { considering the production of organic } \\
\text { coffee, he specifically stated "me } \\
\text { gustaría en algún momento ser un } \\
\text { productor orgánico porque ahora conozco el } \\
\text { valor de mi cafe" ["one day I would like } \\
\text { to become an organic producer because } \\
\text { now I know the value of my coffee"]. } \\
\text { He also has a registered trademark. }\end{array}$ & $\begin{array}{c}\text { He already had a coffee } \\
\text { shop in Neiva before } 2012 \\
\text { but used to sell standard } \\
\text { quality; in } 2012 \text { he started } \\
\text { to sell only his (own) } \\
\text { coffee brands at his shop } \\
\text { and learned to prepare it; } \\
\text { he has another coffee shop } \\
\text { on the road that connects } \\
\text { Neiva to Pitalito. }\end{array}$ & $\begin{array}{l}\text { He did not participate, but he } \\
\text { prepared the coffee for us during } \\
\text { the interview and could describe } \\
\text { it following the SCA lexicon. }\end{array}$ & $\begin{array}{l}\text { He directly exports his coffee to } \\
\text { Germany, the USA and Russia; he } \\
\text { also sells his specialty coffee locally } \\
\text { (roasted and parchment coffee). }\end{array}$ \\
\hline $\begin{array}{l}\text { Producer, } 67 \text {, she inherited the } \\
\text { coffee culture from her parents, } 4 \\
\text { hectares, belongs to an organic } \\
\text { association, retired teacher, widow, } \\
\text { also manages the inherited farm } \\
\text { from her two children }\left(\mathrm{P}_{5}\right) \text {. }\end{array}$ & $\begin{array}{l}\text { The only organic certified producer } \\
\text { visited, she was very much } \\
\text { knowledgeable about the production } \\
\text { rules and methods for organic coffee } \\
\text { production; the main variety cropped } \\
\text { is Castillo*. She has stopped cupping } \\
\text { because she does not obtain the } \\
\text { required score for specialty coffee as of } \\
\text { the SCA scoring. }\end{array}$ & $\begin{array}{l}\text { She values equally the local resources } \\
\text { and farm workers. For her, drinking } \\
\text { coffee means "health". She considers } \\
\text { the treatment given to workers equally } \\
\text { essential: "[el trabajador] no es una } \\
\text { persona que se trata a las patadas, es una } \\
\text { persona de la familia" (("the worker) is } \\
\text { not a person to be } \\
\text { kicked around, it is a person who } \\
\text { belongs to the family"). }\end{array}$ & $\mathrm{n} / \mathrm{a}$ & $\begin{array}{l}\text { She did not participate but defines } \\
\text { her coffee as "salud" (health). } \\
\text { Furthermore, she stated that she } \\
\text { sells a healthy coffee that does not } \\
\text { contaminate the environment. }\end{array}$ & $\begin{array}{l}\text { She mainly sells parchment coffee } \\
\text { to the local cooperative. Informally } \\
\text { she also sells roasted coffee among } \\
\text { her family and friends. Roasting } \\
\text { and packaging take place at the } \\
\text { Universidad Libre de Socorro. }\end{array}$ \\
\hline
\end{tabular}

* Cenicafé advises the growing of varieties such as Castillo, due to its resistance to coffee leaf rust as stated by coffee experts in Huila and Santander. Note: The interviews with producers were possible at this stage only. Contact with roasters was possible at the cupping exercise (Table 4); nevertheless, in-depth interviews with producers and their respective buyers and roasters are planned for a later stage. Source: Own elaboration based on explorative interviews and exchange via WhatsApp with some of the producers for follow up. 
$\mathrm{P}_{4}$ follows a similar pattern as $\mathrm{P}_{1}$, after his coffee was recognized at the Cup of Excellence competition in 2012. $\mathrm{P}_{4}$ already owned a local coffee shop (supplied with conventional/standard coffee). When his coffee was recognized at the Cup of Excellence, he started to valorize it and decided to sell it to the local consumers at his shop. $\mathrm{P}_{4}$ only started to consider green conventions (e.g., organic compost) after the recognition of his coffee. $\mathrm{P}_{4}$ specifically stated that "one day I would like to become an organic producer because now I know the value of my coffee". This symbolic narrative and vision are coupled with the professional coffee brewing in his coffee shop (in-person service quality attribute). $\mathrm{P}_{4}$ not only perceived and acknowledged his coffee (material attributes) but also learned how to brew it. In other words, after the notoriety achieved as a result of the coffee competition, $\mathrm{P}_{4}$ not only adjusted the way he produces coffee (consciously considering environmentally friendly practices), but also became a barista who offers in-person service quality attributes to local consumers (Figure 2).

The interpretative schemes followed by some producers $\left(\mathrm{P}_{1}, \mathrm{P}_{4}\right)$ go beyond (commodity) coffee production and trade by valorizing coffee production, gaining and exchanging knowledge (e.g., with national and international chain actors). This exposure allows them to experiment other interpretative mechanisms of coffee farming and processing in addition to the ones advised in the country. Additionally, producers $\mathrm{P}_{1}, \mathrm{P}_{4}$, and $\mathrm{P}_{5}$ are educating locals to consume quality and healthy coffees.

$\mathrm{P}_{3}$ and his daughter also show an interesting dynamic. Although $\mathrm{P}_{3}$ is relatively new in coffee farming, the exchange with an international buyer/roaster through his daughter boosted the coordination mechanisms to directly start a direct trade after some samples were cupped at destination. The coffee was exported after the coffee drying (material quality) was improved as suggested by the international buyer/roaster. Although this family follows rather domestic market conventions, it has recently started to engage in the specialty coffee niche and in direct trade, mainly driven by external players such as international buyers and roasters. Only a small portion of their coffee is sold as specialty.

While none of the farms in Huila comply with a specific voluntary standard (e.g., Organic, Fairtrade), $\mathrm{P}_{5}$ in Socorro (Santander) was exceptionally committed to Organic (certified) production and to a fair treatment of farm workers without being Fairtrade-certified. $\mathrm{P}_{5}$ defines her coffee as "salud" (health): "I sell a healthy coffee and do not contaminate the environment" (symbolic attribute acknowledged by a producer in the way of practicing quality). Moreover, $\mathrm{P}_{5}$ recognizes the value of farm workers. $P_{5}$ strongly stresses the symbolic value of her coffee as a healthy coffee produced under fair working conditions (green and ethical). She specifically stated "(the worker) is not a person to be kicked around, it is a person who belongs to the family". Nevertheless, $\mathrm{P}_{5}$ also highlighted that her coffee does not reach the SCA score (M2) for the high specialty coffee segment and she does not want to have her coffee cupped anymore. $P_{5}$ makes use of the roasting facilities at the Universidad Libre in Socorro to informally sell her coffee. $\mathrm{P}_{4}$ was the only producer visited to locally add value to this coffee along the coffee chain (e.g., parchment, green (M1 + M2), roasted coffee with his own brand (S1 + S2) sold at his coffee shop for local consumers) (Figure 3).

Cupping results with producers. Only $\mathrm{P}_{1}$ could mention most of the attributes established by the SCA to describe the coffee cup quality such as acidity, body or aftertaste, but he also recognized the importance of resources (e.g., soil) to obtain a good coffee (Table 3). Producers in Huila could identify and relate coffee taste with sweetness (dulzor). Additionally, producers have hardly any experience in cupping and some were shy to share their thoughts about how they identify and describe their coffees.

Cupping results with roasters. Roasters clearly dominate the SCA lexicon for quality description, perception and appreciation (Table 4). It was rather easy for roasters to define the cup quality according to the SCA protocol. Despite the subjectivity in coffee cupping, Austrian roasters were calibrated when giving the score to value the cupped Colombian coffees (Table 4). Producers less familiar with the SCA lexicon use terminology common to them such "buen dulzor" (sweetness) and in some cases the identified taste is related to panela (unrefined whole sugar cane consumed in Central and South America). For instance, this flavor is not present in the SCA flavor wheel (e.g., honey, caramelized, maple syrup) (see [3]). The cupping exercise with roasters served as an entry point to the roaster scene 
in Vienna; however, an interview and further questions could not be truly posed at the coffee event. In-depth interviews with them are planned for a later stage.

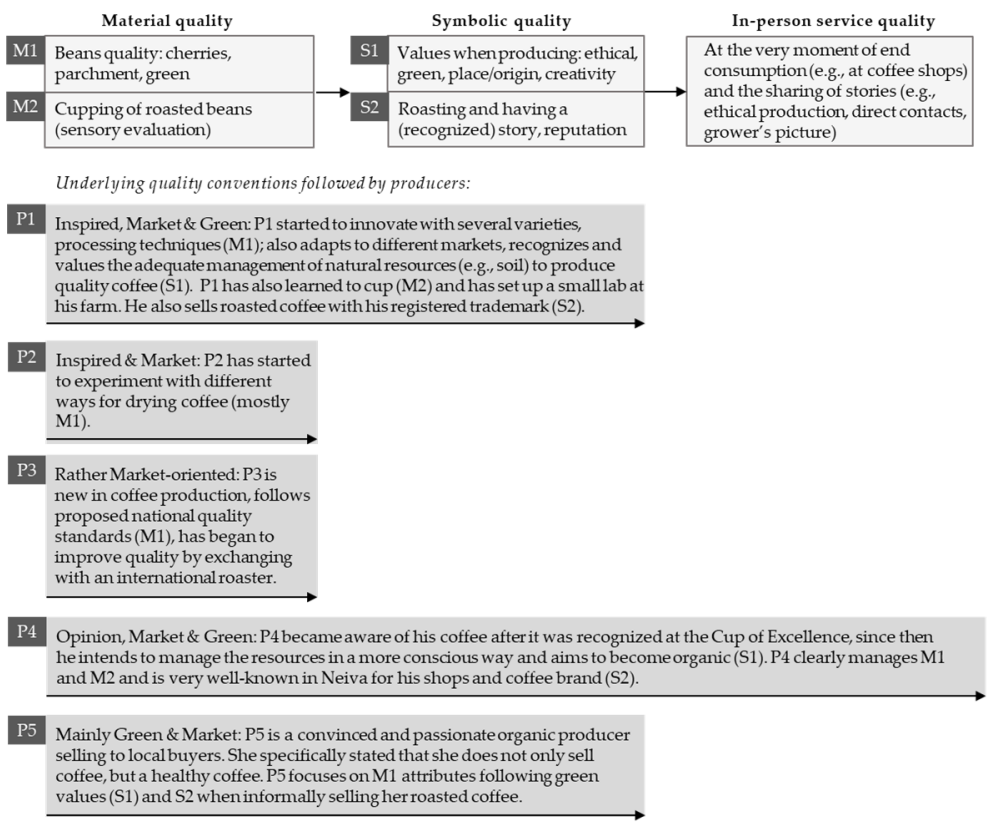

Figure 3. Quality attributes and quality conventions followed by producers. Source: Own elaboration.

Table 4. Quality definition by roasters (based on selected attributes of the SCA protocol).

\begin{tabular}{|c|c|c|c|c|c|c|}
\hline & $\begin{array}{c}\text { Sample } 1 \text { from } \\
\text { PSA }_{1}\end{array}$ & $\begin{array}{c}\text { Sample } 2 \\
\text { from PSA } \\
4\end{array}$ & $\begin{array}{c}\text { Sample } 3 \text { from a } \\
\text { Producer } \\
\text { Suggested by } \\
\text { CRC }\end{array}$ & $\begin{array}{l}\text { Sample } 4 \text { from a } \\
\text { Producer } \\
\text { Suggested by } \\
\text { CRC }\end{array}$ & $\begin{array}{c}\text { Sample } 5 \text { from a } \\
\text { Producer } \\
\text { Suggested by } \\
\text { CRC }\end{array}$ & $\begin{array}{c}\text { Sample } 6 * \text { from an } \\
\text { Association } \\
\text { Contacted by the } \\
\text { Author (Satellite) }\end{array}$ \\
\hline $\begin{array}{l}\text { Fragrancel } \\
\text { aroma- } R_{2}\end{array}$ & Baya/mora (berries) & $\begin{array}{l}\text { Weak, } \\
\text { low, } \\
\text { flat }\end{array}$ & Caramel & $\begin{array}{l}\text { Fruity, } \\
\text { sweet, } \\
\text { peach }\end{array}$ & $\begin{array}{l}\text { Baya/mora (berries) } \\
\text { chocolate }\end{array}$ & Cacao \\
\hline $\begin{array}{l}\text { Fragrance/ } \\
\text { aroma- } R_{3}\end{array}$ & $\begin{array}{c}\text { Cocoa/ } \\
\text { chocolate/ } \\
\text { bitter } \\
\text { chocolate/sweet }\end{array}$ & $\begin{array}{l}\text { Pistachio, } \\
\text { marzipan }\end{array}$ & Peanut & $\begin{array}{c}\text { Nuts, } \\
\text { chocolate }\end{array}$ & Nuts & Fruity, chocolate \\
\hline Acidity $-R_{1}$ & Good & Low & Good & Balanced & High+ & Low \\
\hline Acidity $-R_{2}$ & Medium & Flat & $\begin{array}{l}\text { Medium (as herbs, } \\
\text { rhubarb, honey, } \\
\text { very sweet) }\end{array}$ & Very good & Medium+ & Medium \\
\hline Body- $R_{1}$ & Medium & $\begin{array}{c}\text { Strong, } \\
\text { dry, earthy }\end{array}$ & $\begin{array}{c}\text { Good, } \\
\text { balanced }\end{array}$ & Medium & Flat & Strong \\
\hline Body $-R_{2}$ & Medium+ & Flat & Medium+ & Medium+ & Medium & Medium+ \\
\hline$B o d y-R_{3}$ & Medium & Medium & Medium & Medium & Low-medium & Medium, high \\
\hline$S C A$-score- $R_{1}$ & 83 & 81 & 84 & 85 & 85 & 81 \\
\hline$S C A$-score $-R_{2}$ & 89 & 81.5 & 84.5 & 89 & 86 & 82 \\
\hline SCA-score- $R_{3}$ & 84 & 81 & 85 & 84 & 82 & 82 \\
\hline
\end{tabular}

Note: ${ }^{*}$ The coffee belongs to members of an association (Organic and Fairtrade certified) located in Sierra Nevada de Santa Marta, Magdalena, already known from previous research. Source: Own elaboration.

\section{Discussion}

\subsection{Quality Understanding by Chain Actors and Value Addition by Producers}

Specialty coffees are somehow an alternative and "are linked to environmental and social sustainability, economic justice, and resistance to neoliberalization" [56] (p. 691). Chain actors such 
as producers and roasters are eager to differentiate to make a living out of coffee production in the specialty coffee niche, where the compliance with quality attributes guided by specific conventions is paramount. Normally, conventions are used unconsciously, implicitly, are not apparent as such and not only one but a plurality of conventions are used [35,57].

The study suggests a theoretical framework to identify the quality attributes, conventions and the links to value addition (e.g., cherries, parchment, green, roasted coffee). For instance, $\mathrm{P}_{5}$ mainly achieves material (M1) and symbolic attributes producing and transforming those cherries by consciously taking care of the environment under fair working conditions, however, $P_{5}$ forgoes the cupping scores (M2). $P_{5}$ is able to actively engage along the entire value chain from production, selling abroad and locally (by owning and managing his coffee shops) (Figure 2). $\mathrm{P}_{1}$ is able to add value from the farming to the roasting of his coffee. $\mathrm{P}_{1}, \mathrm{P}_{4}$ and $\mathrm{P}_{5}$ are able to comply with the diverse quality attributes, follow a plurality of quality conventions and are able to add value to their coffee cherries (Figure 2).

In addition to the domestic quality conventions, producers in San Adolfo (Huila) have started to engage in a risky battle for creating their quality definition (e.g., by experimenting with new varieties and varietals, processing techniques or by leading the first specialty coffee competition in San Adolfo). Could this result in an incipient coffee revolution in remote areas once affected by the armed conflict? To what extent can the evolution of quality conventions in the country be encouraged? Conventions are not static and need to evolve (see [58]).

\subsection{Risky Battles Observed in Coffee Quality Definition and Understanding}

The Federation, one of the largest coffee association nowadays representing more than 500,000 coffee producers located in Colombian rural and remote areas, was created in 1927 and elaborated the first domestic quality standards [59]. The organizational and institutional pillars of the Federation are based on a robust coffee system comprising Coffee Grower Committees (State and Municipal Committees), quality control and logistic mechanisms (Almacafé), inspection offices at harbors (Oficinas de Inspección/Almacafé), a product certification office (Cafecert), a research organization (Cenicafé), and an educational/training facility (Fundación Manuel Mejía) [60].

One of the Federation's goals was the worldwide recognition of Colombia as a quality producing country of washed mild Arabicas [61]. Thus, the Federation has a long trajectory in safeguarding the Colombian coffee quality. Cenicafé, the national coffee research center, advises the guiding principles concerning, for instance the type of varieties to be cropped by producers and after-harvest processing techniques to assure the Colombian coffee quality [60]. The first quality conventions were designed in 1927. In the 1980s, federated producers started to engage in trademark protection and from 2005 they comply with geographical indications in Colombia and abroad (i.e., the European Union, Switzerland). Before exporting the coffee bags, all coffee lots are carefully assessed (M1 + M2). The federated system uses Near-Infrared Spectroscopy (NIRS) evaluation machines at Colombian harbors to verify the origin of exported coffees [60]. After the recognition of Café de Colombia, other coffee states with differentiated quality production such as Nariño, Cauca, Huila, Santander, Tolima and Sierra Nevada were identified and national protection was pursued [60].

Some of the visited producers show diverse interpretative schemes to achieve certain quality $(\mathrm{M} 1+\mathrm{M} 2)$ in addition to those proposed by the Federation (e.g., varieties, processing techniques) as a result of external exchanges and exposures. While clearly two producers in Huila $\left(\mathrm{P}_{1}, \mathrm{P}_{4}\right)$ follow several quality conventions (e.g., inspired/inspirational, opinion/notoriety) to position themselves in the specialty coffee sector by using specific varieties and/or following alternative processing techniques, the producer in Socorro, Santander $\left(\mathrm{P}_{5}\right)$ commits to producing a symbolic healthy coffee using the endorsed varieties (e.g., ecological/green conventions) and the advised processing techniques (e.g., local market conventions) by Cenicafé, following ethical principles. In a country where the coffee sector is guided by a strong coffee authority, one can observe some types of ruptures for applying specific quality conventions. Thus, the risky battle for creating producers' quality definitions may 
take place in many battle lines, not only between producers and roasters, but also between producers within the same country or region.

Producers such as $P_{1}$ challenge the use of specific varieties and processing techniques. This implies that the coordination mechanisms can vary due to the individual or collective innovative capacity followed by producers (inspired or opinion/notoriety) to confront the volatility of coffee prices (as faced by $\mathrm{P}_{1}$ 's father when thinking about selling the family farm). There is also a risky battle for producers to create alternative quality definitions as a result of the exchanges with external actors (international roasters/buyers). Indeed, the first specialty coffee competition in San Adolfo-Feria del Bourbon Rosado - enhances what corporate-driven chain actors belonging to the specialty coffee sector look for, namely, innovation, inspiration and new ways of doing things to be then recognized and valued by final consumers in contrast to the sameness and minimum requirements for which the conventional market stands for.

Another type of risky battle and rupture is when producers, such as $\mathrm{P}_{3}$ and his daughter, are confronted with the direct exchange with external actors (buyers/roasters) but mainly follow the guidelines proposed by the Colombian coffee authority to achieve a certain quality. This situation may be characterized as a result of governance at a distance suggesting a "roaster-driven" quality definition penetrating the producers' community.

Roasters possess all information, dominate the quality lexicon (Table 4) in the specialty niche and craft the best "assemblage" of those coffees by origins, "recipes" or blends to satisfy customers (retailers) and end consumers. Those who usually have the knowledge, set the rules and own the financial means (e.g., to set roasting profiles) are the ones who exert diverse types of power over others $[5,6]$. Coffee producers at origin heavily depend on gatekeepers such as buyers, roasters, cuppers, Q-graders (mainly based elsewhere) to evaluate their coffee. At the end, they are the ones who decide if their coffees are "good" or "bad" coffees (see [3], presenting the case in Guatemala).

I had the opportunity to attend the Hamburg Transparency Colloquium held in June 2018, where specialty roasters discussed the importance of transparency in the coffee sector. Many of these specialty roasters, also engaging in direct trade, aimed to look for alternatives that go beyond higher prices setting for specialty coffee, quality parameters/rules or sharing pictures or information about producers. These cannot be the only relevant justifications to engage in direct relationships in the specialty coffee niche [32]. For instance, climate change is a real threat, and roasters are concerned about the future of coffee sourcing. Despite these great efforts, at the Transparency Meeting I did not see any of those small producers engaging in the discussions and debates.

\section{Conclusions}

Overall, diverging quality conventions, understood as interpretative schemes for actors, in a country with a strong coffee regulation such Colombia, can follow diverse "risky" battles and ruptures to re-define and accrue quality. It is not only about the influence of external actors (roasters/buyers) to exert power over producers to coordinate the delivery of outstanding and innovative physical attributes (i.e., farming practices, number of defects, cup score), but also about the contestation with national regulatory frameworks to be followed by producers to preserve the Colombian coffee quality and make a (more or less secure) living out of it.

In other words, the divergences and risky battles and ruptures in quality understanding and construction by producers are not only based on "roaster-driven" quality definitions penetrating the producers' community, or the knowledge gained by outstanding/innovative producers, but are also based on the regulatory (i.e., quality-related) frameworks followed by producers within a country with a robust coffee Federation aiming to preserve a well-known product (Café de Colombia). The issue is not about picking one blueprint solution or a single way of doing things, but enlarging the view on how quality in the specialty coffee niche might evolve, be understood, achieved and transmitted to producers to avoid confusion, pitfalls and distrust. 
Producers who valorize and understand coffee farming are starting their own quality experiments to construct and practice quality, have the potential to conquer national and international markets but also to advance and add value along the coffee value chain (Figure 2). This implies that these producers are able to comply with diverse quality attributes, to follow a plurality of quality conventions and to add value to their harvested cherries. The proposed theoretical approach linking quality attributes, quality conventions and value addition contributes to the debate and narratives of the quality turn in the agro-food studies, its evolution and the governance of global supply chains.

Producers have slowly started to value and recognize their coffee beyond material attributes. Quality definitions need to go beyond strict material attributes (M1) mostly understood by specialty producers. Coffee producers at origin are heavily dependent on roasters, cuppers, Q-graders to evaluate/value their coffee (M1 + M2). In the end, they are the ones who decide if their coffee is "good" or "bad". There is even a rupture in the understanding of physical attributes (M1) of cherries, parchments or green beans and the cupping assessments (M2) of the roasted beans based on the protocol of the Specialty Coffee Association (United States, Europe). The understandings of quality and construction are also about integrating symbolic attributes, conventions (e.g., inspired, green) and the ability to transmit the information to the final consumers (in-person service quality attribute). Indeed, agro-ecological, organic production practices or biodiversity (but also ethical labor principles) need to be acknowledged when defining and constructing quality to face pressing environmental and social challenges in the coffee culture (see $[62,63]$ ).

It seems that quality as acknowledged by the SCA (and followed by their members) falls short. The fact that producing countries have started to consume their specialty coffee only recently also contributes to the divergences in the understandings of quality, conventions and the position of producers to add value. Thus, some questions still arise: How can the coffee establishment (nationally (e.g., robust producers' organizations) or internationally (e.g., SCA)) further promote direct interactions and relationships, exchange and dialogue between producers and other chain actors (e.g., roasters) apart from coffee competitions (e.g., Cup of Excellence) or large coffee meetings (e.g., coffee expo, festivals) to oversee the "risky battles" and ruptures to deal with evolving quality conventions? To what extent might rooted national institutional settings followed by producers boost or hinder the quality evolution and re-definition (e.g., through guided experimentation) as well as local consumption? If Colombians are so proud of a product that is mainly consumed abroad, how can chain actors (such as caficultores) truly from below internalize, value and justify production and processing practices endeavored to construct their own quality conventions to make a living out it, if their produce is not further processed and consumed by themselves? Despite all acknowledged national efforts and achievements (see [64]), the coffee drinking experience needs to be further customized considering the great variety of Colombian origins and roasting profiles similar to the consumption of fine wines (see $[65,66])$.

In the words of a roaster, "what defines specialty coffee cannot be just (material) quality. A coffee cannot be special if it is not sustainable. How can you celebrate the bean and not treasure the planet and people that brought it to us? This should and could be done as consistently and quantitatively as we now measure $Q$ grades" [67] (n.pag.). Certainly, a more transparent and inclusive dialogue between chain actors is needed to reduce the divergences and imbalances concerning the quality understandings and value appropriation among actors of global coffee value chains. This paper proposes a theoretical framework that connects quality attributes and conventions and the links to value addition. However, more in-depth research involving a variety of chain actors (producers and their specific buyers, roasters, consumers) is essential to reveal far-reaching and inclusive narratives of the quality turn in the specialty coffee niche.

Funding: This research was funded by the Austrian Science Fund, grant number T960-G27.

Acknowledgments: I am truly grateful to all interview partners in Acevedo/San Adolfo, Neiva (Huila) and in Socorro (Santander) during the fieldwork in Colombia and the roasters in Vienna, Austria. I also kindly thank the Cesurcafé staff members (led by Nelson Gutiérrez-Guzmán) from Universidad Surcolombiana in Neiva, Huila 
and Edis Mauricio Sanmiguel from Universidad Libre (Socorro, Santander) for their helpful support during the fieldwork. I am also very grateful to Katharina Pernkopf for the insightful discussions and the shared tips before fieldwork. Likewise, I am thankful to Rainer Diaz-Bone, Marianne Penker, and Christian Vogl for commenting on the initial version of the manuscript and for the valuable feedback from anonymous reviewers. I kindly wish to thank Christina Roder for the editorial support.

Conflicts of Interest: The author declares no conflict of interest.

\section{References}

1. Holland, E.; Kjeldsen, C.; Kerndrup, S. Coordinating quality practices in Direct Trade coffee. J. Cult. Econ. 2015, 9, 186-196. [CrossRef]

2. Fischer, E.F. Quality and inequality: Creating value worlds with Third Wave coffee. Socio Econ. Rev. 2019, 44. [CrossRef]

3. Fischer, E.F.; Victor, B.; De Barrios, L.A. Quality versus solidarity: Third Wave coffee and cooperative values among smallholding Maya farmers in Guatemala. J. Peasant Stud. 2020, 1-18. [CrossRef]

4. Vicol, M.; Neilson, J.; Hartatri, D.F.S.; Cooper, P. Upgrading for whom? Relationship coffee, value chain interventions and rural development in Indonesia. World Dev. 2018, 110, 26-37. [CrossRef]

5. Dallas, M.; Ponte, S.; Sturgeon, T. A Typology of Power in Global Value Chains; Working Paper in Business and Politics 92; Copenhagen Business School: Copenhagen, Denmark, 2017; ISBN 978-879-357-100-6.

6. Grabs, J.; Ponte, S. The evolution of power in the global coffee value chain and production network. J. Econ. Geogr. 2019, 19, 803-828. [CrossRef]

7. Panhuysen, S.; Pierrot, J. Coffee Barometer. Available online: https://www.hivos.org/assets/2018/06/CoffeeBarometer-2018.pdf (accessed on 13 June 2019).

8. Samper, L.F.; Quiñones-Ruiz, X.F. Towards a Balanced Sustainability Vision for the Coffee Industry. Resources 2017, 6, 17. [CrossRef]

9. Daviron, B.; Ponte, S. The Coffee Paradox. Global Markets, Commodity Trade and the Elusive Promise of Development; Zed Books: London, UK; New York, NY, USA, 2005; ISBN 9781842774564.

10. Bray, J.; Neilson, J. Examining the interface of sustainability programmes and livelihoods in the Semendo highlands of Indonesia. Asia Pac. Viewp. 2018, 59, 368-383. [CrossRef]

11. Dietz, T.; Auffenberg, J.; Chong, A.E.; Grabs, J.; Kilian, B. The Voluntary Coffee Standard Index (VOCSI). Developing a Composite Index to Assess and Compare the Strength of Mainstream Voluntary Sustainability Standards in the Global Coffee Industry. Ecol. Econ. 2018, 150, 72-87. [CrossRef]

12. Elder, S.D.; Lister, J.; Dauvergne, P. Big retail and sustainable coffee: A new development studies research agenda. Prog. Dev. Stud. 2013, 14,77-90. [CrossRef]

13. FAO (Food and Agriculture Organization of the United Nations). Impact of International Voluntary Standards on Smallholder Market Participation in Developing Countries-A Review of Literature; Agribusiness and Food Industries Series; FAO: Rome, Italy, 2014; Available online: http://www.fao.org/3/a-i3682e.pdf (accessed on 20 May 2016).

14. Grabs, J. Assessing the institutionalization of private sustainability governance in a changing coffee sector. Regul. Gov. 2020, 14, 362-387. [CrossRef]

15. Guthman, J. The Polanyian Way? Voluntary Food Labels as Neoliberal Governance. Antipode 2007, 39, 456-478. [CrossRef]

16. Levy, D.; Reinecke, J.; Manning, S. The Political Dynamics of Sustainable Coffee: Contested Value Regimes and the Transformation of Sustainability. J. Manag. Stud. 2015, 53, 364-401. [CrossRef]

17. Muradian, R.; Pelupessy, W. Governing the coffee chain: The role of voluntary regulatory Systems. World Dev. 2005, 33, 2029-2044. [CrossRef]

18. Mutersbaugh, T. Serve and certify: Paradoxes of service work in organic coffee certification. In Confronting the Coffee Crisis: Fair Trade, Sustainable Livelihoods and Ecosystems in Mexico and Central America; Bacon, C.M., Méndez, V.E., Gliessman, S.R., Goodman, D., Fox, J.A., Eds.; The MIT Press: Cambridge, MA, USA; London, UK, 2008; pp. 261-288. [CrossRef]

19. Schouten, G.; Bitzer, V. The emergence of Southern standards in agricultural value chains: A new trend in sustainability governance? Ecol. Econ. 2015, 120, 175-184. [CrossRef] 
20. Alvarez, G.; von Hagen, O. The Impacts of Private Standards on Producers in Developing Countries. Literature Review Series on the Impact of Private Standards_Part II; International Trade Centre: Geneva, Switzerland, 2011. [CrossRef]

21. Rueda, X.; Lambin, E.F. Linking Globalization to Local Land Uses: How Eco-Consumers and Gourmands are Changing the Colombian Coffee Landscapes. World Dev. 2013, 41, 286-301. [CrossRef]

22. Geiger-Oneto, S.; Arnould, E.J. Alternative Trade Organization and Subjective Quality of Life. J. Macromarketing 2011, 31, 276-290. [CrossRef]

23. Raynolds, L.T.; Murray, D.; Taylor, P.L. Fair trade coffee: Building producer capacity via global networks. J. Int. Dev. 2004, 16, 1109-1121. [CrossRef]

24. Djama, M.; Fouilleux, E.; Vagneron, I. Standard-Setting, Certifying and Benchmarking: A Governmentality Approach to Sustainability Standards in the Agro-Food Sector. In Governing through Standards: Origins, Drivers and Limitations; Ponte, S., Gibbon, P., Vestergaard, J., Eds.; Palgrave Macmillan: Basingstoke, UK, 2011; pp. 184-209, ISBN 978-0-230-29540-7.

25. Brown, N. Coffee Producers Demand Immediate Action Amidst Price Crisis. Available online: https:// dailycoffeenews.com/2019/03/27/coffee-producers-demand-immediate-action-amidst-price-crisis/ (accessed on 28 March 2019).

26. Brown, N. Spp Global Denounces Coffee Prices, Calls for Living Income. Available online: https:// dailycoffeenews.com/2019/04/22/spp-global-denounces-coffee-prices-calls-for-living-income/ (accessed on 24 April 2019).

27. Boydell, H. Rethinking the C Price: Should We Change how We Price Coffee? Available online: https://www. perfectdailygrind.com/2018/10/rethinking-the-c-price-should-we-change-how-we-price-coffee/ (accessed on 20 May 2019).

28. Gilbert, C.L. Value chain analysis and market power in commodity processing with application to the cocoa and coffee sectors. In Governance, Coordination and Distribution along Commodity Value Chains, Proceedings of the FAO Commodities and Trade Proceedings 2, Rome, Italy, 4-5 April 2006; FAO: Rome, Italy, 2006; pp. 267-295, ISBN 978-92-5-105748-3. Available online: http://www.fao.org/3/a1171e/a1171e00.htm (accessed on 13 June 2019).

29. Wollni, M.; Zeller, M. Do farmers benefit from participating in specialty markets and cooperatives? The case of coffee marketing in Costa Rica1. Agric. Econ. 2007, 37, 243-248. [CrossRef]

30. Deugd, M. Crisis del Cafe: Nuevas Estrategias y Oportunidades; RUTA: San Jose, Costa Rica, 2003.

31. Maertens, M.; Swinnen, J.F.M. Globalization, privatization, and vertical coordination in food value chains in developing and transition countries. J. Agric. Econ. 2007, 37, 89-102. [CrossRef]

32. MacGregor, F.; Ramasar, V.; Nicholas, K.A. Problems with Firm-Led Voluntary Sustainability Schemes: The Case of Direct Trade Coffee. Sustainability 2017, 9, 651. [CrossRef]

33. Brown, N. Direct Trade is Dead, Long Live Its Founding Principles. Available online: https://dailycoffeenews. com/2017/05/10/direct-trade-is-dead-long-live-its-founding-principles/ (accessed on 10 June 2019).

34. Marescotti, A. Marketing channels, quality hallmarks and the theory of convention. In The Socio-Economics of Origin Labelled Products in Agro-Food Supply Chains: Spatial, Institutional and Co-ordination Aspects, Proceedings of the 67th EAAE Seminar, Le Mans, France, 28-30 October 1999; Sylvander, B., Barjolle, D., Arfin, F., Eds.; Serie Actes et Communications 17-2; INRA: Versailles, France, 2000; pp. 103-122, ISBN 978-273-800-949-4.

35. Diaz-Bone, R. Economics of conventions and its perspective on knowledge and institutions. In Knowledge and Institutions, Knowledge and Space; Glückler, J., Suddaby, R., Lenz, R., Eds.; Springer: Cham, Switzerland, 2018; Volume 13, pp. 69-88. [CrossRef]

36. Hernandez-Aguilera, J.N.; I Gómez, M.; Rodewald, A.D.; Rueda, X.; Anunu, C.; Bennett, R.; Van Es, H.M. Quality as a Driver of Sustainable Agricultural Value Chains: The Case of the Relationship Coffee Model. Bus. Strat. Environ. 2018, 27, 179-198. [CrossRef]

37. Busch, L. The moral economy of grades and standards. J. Rural Stud. 2000, 16, 273-283. [CrossRef]

38. Boltanski, L.; Thévenot, L. De la Justification: Les Economies de la Grandeur; NRF Essais-Gallimard: Paris, France, 1991; ISBN 978-207-072-254-9.

39. Ponte, S. Convention theory in the Anglophone agro-food literature: Past, present and future. J. Rural Stud. 2016, 44, 12-23. [CrossRef]

40. Rosin, C.; Campbell, H. Beyond bifurcation: Examining the conventions of organic agriculture in New Zealand. J. Rural Stud. 2009, 25, 35-47. [CrossRef] 
41. Diaz-Bone, R.; Salais, R. Economics of convention and the history of economies. Towards a transdisciplinary approach in economic history. Hist. Soc. Res. 2011, 36, 7-39. Available online: https://www.jstor.org/stable/ 23032283 (accessed on 19 June 2019).

42. Sylvander, B.; Belletti, G.; Marescotti, A.; Thévenod-Mottet, E. Establishing a quality convention, certifying and promoting the quality of animal products: The case of beef. In Livestock Farming Systems—Product Quality Based on Local Resources Leading to Improved Sustainability; Rubino, R., Sepe, L., Dimitriadou, A., Gibon, A., Eds.; EAAP Scientific Series Volume 118; Wageningen Academic Publishers: Wageningen, The Netherlands, 2006; pp. 61-82. [CrossRef]

43. Busch, L. Standards: Recipes for Reality; MIT Press: Cambridge, MA, USA, 2011; ISBN 978-026-201-638-4.

44. Boltanski, L.; Thévenot, L. On Justification: Economies of Worth; Princeton University Press: Princeton, NJ, USA; Oxford, UK, 2006; ISBN 978-0-691-11837-6.

45. Leroy, T.; Ribeyre, F.; Bertrand, B.; Charmetant, P.; Dufour, M.; Montagnon, C.; Marraccini, P.; Pot, D. Genetics of coffee quality. Braz. J. Plant Physiol. 2006, 18, 229-242. [CrossRef]

46. ISO (International Organization for Standardization). ISO 9000:2015. Quality Management Systems_Fundamentals and Vocabulary. Available online: https://www.iso.org/standard/45481.html (accessed on 13 June 2019).

47. Rangnekar, D. The Socio-Economics of Geographical Indications: A Review of Empirical Evidence from Europe; International Centre for Trade and Sustainable Development (ICTSD): Geneva, Switzerland; United Nations Conference on Trade and Development (UNCTAD): Geneva, Switzerland, 2004; Available online: https: //unctad.org/en/PublicationsLibrary/ictsd2004ipd8_en.pdf (accessed on 19 June 2019).

48. Nelson, P. Information and Consumer Behavior. J. Polit. Econ. 1970, 78, 311-329. [CrossRef]

49. Darby, M.R.; Karni, E. Free Competition and the Optimal Amount of Fraud. J. Law Econ. 1973, 16, 67-88. [CrossRef]

50. The Coffee Corner. What is the SCA? Available online: https://coffeecorner.com/blog/general/what-is-thesca-full-list-of-sca-approved-coffee-makers/ (accessed on 13 June 2019).

51. SCA (Specialty Coffee Association). What is Specialty Coffee. Available online: https://sca.coffee/research/ what-is-specialty-coffee (accessed on 12 June 2019).

52. SCA (Specialty Coffee Association). Protocols \& Best Practices. Available online: https://sca.coffee/research/ protocols-best-practices (accessed on 20 May 2019).

53. Gutiérrez-Guzmán, N.; Cortés-Cabezas, A.; Iv, E.C. A novel tasting platform for sensory analysis of specialty coffee. Coffee Sci. 2018, 13, 401-409. [CrossRef]

54. Tröster, B.; Staritz, C. Global Commodity Chains, Financial Markets, and Local Market Structures: Price Risks in the Coffee Sector in Ethiopia; ÖFSE-Austrian Foundation for Development Research: Vienna, Austria, 2015.

55. Crouch, M.; McKenzie, H. The logic of small samples in interview-based qualitative research. Soc. Sci. Inf. 2006, 45, 483-499. [CrossRef]

56. West, P. Making the Market: Specialty Coffee, Generational Pitches, and Papua New Guinea. Antipode 2010, 42, 690-718. [CrossRef]

57. Kanamaru, T. Production management as an ordering of multiple qualities: Negotiating the quality of coffee in Timor-Leste. J. Cult. Econ. 2020, 13, 139-152. [CrossRef]

58. Marescotti, A.; Quiñones-Ruiz, X.F.; Edelmann, H.; Belletti, G.; Broscha, K.; Altenbuchner, C.; Penker, M.; Scaramuzzi, S. Are Protected Geographical Indications Evolving Due to Environmentally Related Justifications? An Analysis of Amendments in the Fruit and Vegetable Sector in the European Union. Sustainability 2020, 12, 3571. [CrossRef]

59. Barjolle, D.; Quiñones-Ruiz, X.F.; Bagal, M.; Comoé, H. The Role of the State for Geographical Indications of Coffee: Case Studies from Colombia and Kenya. World Dev. 2017, 98, 105-119. [CrossRef]

60. Quiñones-Ruiz, X.F.; Penker, M.; Vogl, C.R.; Samper Gartner, L.F. Can origin labels re-shape relationships along international supply chains? Int. J. Commons 2015, 9, 419-439. Available online: https://www.jstor.org/ stable/26522831 (accessed on 10 June 2019). [CrossRef]

61. Reina, M.; Samper, L.F.; Fernández, M.P. La Estrategia Detrás de La Marca, 1st ed.; Ediciones B: Bogotá, Colombia, 2007; ISBN 978-958-8294-23-0.

62. Folch, A.; Planas, J. Cooperation, Fair Trade, and the Development of Organic Coffee Growing in Chiapas (1980-2015). Sustainability 2019, 11, 357. [CrossRef] 
63. Vogt, M.A. Developing stronger association between market value of coffee and functional biodiversity. J. Environ. Manag. 2020, 269, 110777. [CrossRef]

64. FNC (Federación Nacional de Cafeteros de Colombia). Dinámica del Consumo Interno de Café en Colombia. Programa de Promoción de Consumo Toma Café. Available online: https://www.federaciondecafeteros.org/ static/files/2Dinamica_del_consumo_interno_de_cafe.pdf (accessed on 13 June 2019).

65. Boaventura, P.S.M.; Abdalla, C.C.; Araujo, C.; Arakelian, J.S. Value co-creation in the specialty coffee value chain: The third-wave coffee movement. Rev. Adm. Empres. 2018, 58, 254-266. [CrossRef]

66. Spence, C.; Carvalho, F.M. Assessing the influence of the coffee cup on the multisensory tasting experience. Food Qual. Prefer. 2019, 75, 239-248. [CrossRef]

67. Rogers, L. Unraveling the Mystery of Coffee Prices: One Roaster's Journey. Available online: https: //dailycoffeenews.com/2019/07/15/unraveling-the-mystery-of-coffee-prices-one-roasters-journey/ (accessed on 30 July 2019).

2020 by the author. Licensee MDPI, Basel, Switzerland. This article is an open access article distributed under the terms and conditions of the Creative Commons Attribution (CC BY) license (http://creativecommons.org/licenses/by/4.0/). 